Sofija D. Stefanovic ${ }^{*}$

Filološki fakultet

Univerzitet u Beogradu https://doi.org/10.18485/analiff.2020.32.2.4

821.111(73).09 Пинчон Т.

Originalni naučni rad

Primljen: 13.03 .2020

Prihvaćen: 18.06.2020

\title{
KOMPARATIVNA ANALIZA ELEMENATA POSTMODERNE U „ENTROPIJI“ I OBJAVI BROJA 49
}

U radu se istražuju popularni elementi i motivi koji se nalaze u književnosti i umetnosti postmodernizma na primeru književnih dela koja je napisao autor Tomas Pinčon (Thomas Pynchon). Upotrebom komparativne analize će se porediti njegova kratka priča „Entropija“ i roman Objava broja 49. Čitaocima će se ukazati na povezanost ova dva dela, kao i na razvijanje elemenata navedenih u radu koji su pronađeni u „Entropiji“, što je i prouzrokovalo njihovu kasniju primenu i u romanu. Neki od analiziranih elemenata su: simulakrum, identitet, dehumanizacija, preklapanje žanrova, obamrlost i prouzrokovanje obamrlosti (zlo)upotrebom raznihpsihoaktivnihsupstanci, konzumerizam, medijska manipulacija, itd. U tekstu će takođe biti reči i o onim karakterističnim elementima postmoderne koje ne dele i kratka priča i roman, već se pojavljuju u jednom ili drugom delu. Na taj način, ovaj rad ne predstavlja isključivo komparativnu analizu „Entropije“ i Objave broja 49, već i zasebne analize oba književna dela kroz prizmu postmoderne i njenih karakteristika.

Ključne reči: „Entropija“, Objava broja 49, Thomas Pynchon, postmoderna, komparativna analiza, elementi postmodernizma.

\section{UVOD}

\subsection{Postmoderna i njene karakteristike}

Kada bismo upitali ljubitelje starijih umetničkih pravaca, recimo ruskih klasika, koje je njihovo mišljene o postmodernoj izložbi koja je u toku, ili o nekoj slici, romanu, ili kratkoj priči, njihov odgovor bi se verovatno poklapao sa Batlerovim citatom: „Podstiče nas da postavljamo pitanja o njenom kontekstu, a ne o sadržaju: „Koja je svrha ovoga?” ili „Zbog čega je ovo izloženo u muzeju?””(Butler, 2002: 1)1. Moguće je da

\footnotetext{
sofstefanovicb2@gmail.com

1 Citat je prevod autora, kao i svi naredni citati strane literature.
} 
je to usled mišljenja da umetnost mora biti „lepa“ ili privući pažnju svojom složenošću, što je dovelo do stereotipa da je postmoderna umetnost „,bez poente“, ,jednostavna“ ili ,površna“, dakle samim tim i „manje značajna“ kao umetnički pravac. Ona je kao odgovor na pitanja odozgo ponudila još pitanja: „Šta je lepo? Zašto se nešto što nije realno pretvara da predstavlja stvarnost u toliko detalja, kada to nikada neće biti? I šta je uopšte stvarno i realno?" Postmoderna umetnost je time narušila dotadašnje kriterijume i svojom naizgled površnošću ukazala na površnost standarda za ocenjivanje umetnosti: „O surfikciji se neće suditi po istim principima. Ona neće biti ni dobra ni loša, istinita ili lažna, lepa ili ružna. Ona će jednostavno biti, i njena svrha će prvenstveno biti da razotkrije sopstvenu fikcionalnost, da otkrije metaforu sopstvene varljivosti i simulakruma, kao i da se više ne pretvara da može predstavljati realnost, istinu ili lepotu“"(Federman, 2001: 68).

Takođe, može se postaviti i pitanje - ako umetnost mora biti lepa, a samim tim i dopadljiva čitaocu, da li to znači da se ona i stvara radi čitaoca i za njega. I, ako je to tačno, da li onda publika ceni umetničko delo samo zbog onoga što predstavlja, samo jer je dopadljvo? I po čemu se onda umetnici u teoriji razlikuju od nekakvih zanatlija koji rade po porudžbini? „Očigledna je proizvoljnost ove istorije i ona čini nažao složenosti umetničke aktivnosti, jer umetnost se poistovećuje sa malim brojem dela koja se prave, čitaju i uživaju. [...] Najbolja umetnost je ona koja dovodi u pitanje zvanična ograničenja. Najbolja publika je ona koja je sposobna da ceni takvu umetnost... Subjektivnost i objektivnost nestaju, sve je splet reči, pisanje više nije ogledalo stvarnosti“" (Steiner, 2007: 432). Osim toga što nam Steiner udeljuje kompliment o tome kakva smo publika kao obožavatelji ovog književnog pravca, on i ukazuje na preokret književnosti od realističnog ka metafiktivnom. Ovo je potvrdio i Federman, dodajući i kako je književnost postmoderne u stvari književnost pomeranja granica, jer toliko nerealno delo nikada nije delovalo istinitije, toliko podsvesnog nikada nije bilo prikazano na ljudskoj površini, niti su očigledne laži i apsurdne izjave delovale uverljivije: „Stoga, u fikciji sadašnjosti i budućnosti, sve će razlike biti ukinute između stvarnog i izmišljenog, između svesnog i podsvesnog, prošlosti i sadašnjosti, između istine i neistine“ (2001: 67). Postmoderna je pomerala granice umetnosti i opredelila se za svakodnevno, što ju je na neki način i učinilo realnijom: „Ipak, najradikalnije pređene granice su one između fikcije i nefikcije i, samim tim, između umetnosti i života“" (Hutcheon, 1988: 10). 
Postavlja se pitanje kako onda analizirati nešto što je životno, kada je i samim čitaocima nepoznat smisao samog života. Spektar postmoderne književnosti obuhvata sve od obamrlosti do šizofrenije, od kiborga do konzumerizma, od distopije do preklapanja žanrova, stoga se javlja pitanje kako da znamo da čitamo upravo pisca ovog pravca: „Bez sumnje, ovi nazivi su previše heterogeni da bi sačinili pokret, paradigmu ili školu. Ipak, oni mogu prizvati određeni broj kulturnih tendencija, sazvežđe vrednosti, repertoar procedura i stavova. Ovo nazivamo postmodernom“ (Hassan, 1993: 147). Istina je da možemo pokušavati da pobrojimo i klasifikujemo sve elemente postmoderne, ali je nemoguće naći jedan zajednički element koji bi se javio u svim književnim delima. Takođe je nemoguće pokušati da pobrojimo sve karakteristike ovog pravca u kratkim crtama, jer se mnogi preklapaju, nadovezuju, pa čak i suprotstavljaju ostalima.

Stoga bi pokušaji da se od ovog uvoda u rad napravi uvod u postmodernizam bili uzaludni i bezuspešni, jer su se o tome pisali tomovi: „Postmodernizam je, naravno, samo deo celokupnog pejzaža, ali nalik planinskom vencu on je nadvisio sve ostalo, a pešačiti preko njegovih vrhova i dolina nije lak zadatak" (Lewis, 1998: 122). Nije potrebno tražiti postmoderno u Pinčonu, već naći Pinčona u postmodernom - locirati ga u koordinantnom sistemu motiva i elemenata od kojih se pravac sastoji.

\subsection{Tomas Pinčon, „Entropija” i Objava broja 49}

Dela Tomasa Pinčona, njegovi romani i kratke priče, postala su enciklopedije ili rečnici postmoderne. Ova epoha je postala „njegova“, a njegovo ime sinonim za postmodernu književnost: „U Času anatomije, Filip Rotov Cukerman dobija pismo od urednika školskih novina sa njegovog nekadašnjeg fakulteta. Želeli su da ga pitaju o budućnosti njegove vrste fikcije u postmodernoj eri Džona Barta i Tomasa Pinčona“"(Steiner, 2007: 427).

„Pinčon (rođen 1937. godine) nije bio svedok ratu, već nadahnuti, povremeno kič fantazista, čiji se preodređeni zapleti vezuju za raketnu tehniku i tehnologiju kao sponu između seksa, izumiranja i apokalipse“" (Dickstein, 2007: 122), opis je koji je samo zagrebao površinu njegovog stvaralaštva unutar okvira postmoderne. Kao i ona sama, njegova dva dela o kojima je reč u radu se sastoje od znatnog broja raznih elemenata, ,nagomilanih" u jednu celinu, ili, kako je opisan grad u citatu iz Objave broja 49, što veoma podseća i na sam pravac: „San Narciso bio je dalje na jugu, blizu Los Anđelesa. Nalik mnogim mestima u Kaliforniji, bio je manje 
prepoznatljivi grad, a više skupina pojmova“ (Pynchon, 2012: 15). „Entropija“, koja je hronološki prethodila romanu, najavljuje mnoge motive i karakteristike koji se mogu pronaći i u Objavi broja 49. Ova dva književna dela zajedno mogu čitaocima dati zadovoljavajuću teoretsku osnovu za dalje prepoznavanje elemenata postmodernog, kao i shvatanje zbog čega je ovaj period nazvan ,pinčonovski“.

Mizanscen kratke priče je takav da čitaoci vide „kadrove“, tj. nalik jednom snimljenom niznom kadru koji prelazi sa grupe na grupu ljudi u stanu Ćufte Maligena, pre nego što usledi druga scena u stanu ispod sa dvoje ljudi: „Uvod u „Entropiju“ daje malo složeniji način prikazivanja junaka koji se nalaze u okviru priče -pripovjedač se ne zaustavlja samo na jednoj grupi, nego prelazi sa jedne na drugu“ (Macura, 2014: 182). Kontrasti koji se javljaju između dva stana i naizgled dva različita sveta omogućavaju ovoj priči da ne samo predstavi elemente postmoderne koji proističu jedan iz drugog, već se i suprotstavljaju. „Pinčonova kratka priča „Entropija” pretvara ovu estetičku uzrujanost u opštu anksioznost oko budućnosti sveta, čija energija polako ali sigurno opada“ (Steiner, 2007: 430) - sam kraj ove kratke priče aludira i na kraj sveta, što potvrđuje Dikstajnov citat o Pinčonovoj apokalipsi, i implicira da će se svet završiti upravo onako kako je prethodno i T. S. Eliot smatrao da hoće - ne uz eksploziju ili katastrofu, već polako zamirući, uz iscrpljenost i postepeno zapadanje u zaborav, kao i žurka Ćufte Maligena.

Dosledno „Entropiji“, Pinčonov roman prati apsurdnu vezu između događaja, ljudi i njihovih reakcija, uzroka i posledica: „Karakteristika koja definiše Objavu broja 49 (kao i sve Pinčonove romane), međutim, jeste stepen do kog su ne samo likovi, već i čitaoci uključeni u nesigurnost koju priča odaje“ (Harper, 1994: 167). Objava broja 49 će nas navesti da razmišljamo o sličnim pitanjima kao onima sa početka rada: „Otkud ovaj događaj i zašto se nalazi baš ovde?" Ono što upravo doprinosti postmodernoj uverljivosti ovog romana jeste to što nismo jedini - likovi dele našu zbunjenost i podjednako su nepouzdani i puni mana kao i mi: „Nestabilnost fiktivnog sveta u kom pronalazimo sebe i poteškoće koje imamo tokom spoznavanja istog na pouzdani način, očigledna je u mnogim delima postmoderne fikcije... U takvim delima, proste činjenice o svetu u romanu su kontradiktorne, moguće je da nema pouzdanog centra svesti, a narator, na primer Edipa Mas u Pinčonovoj Objavi broja 49 (1967), može biti u potpunosti zbunjen, ili čak možda i lud, tačnije u tom dvosmislenom 
KOMPARATIVNA ANALIZA ELEMENATA POSTMODERNE U „ENTROPIJI“ I ...

mentalnom stanju koje utiče na popriličan broj postmodernih protagonista“" (Butler, 2002: 69).

\section{ANALIZA}

Pre upuštanja u komparativnu analizu, što je i svrha ovog rada, trebalo bi spomenuti motive i elemente koji se ne nalaze u oba dela.

Pa ipak, primetna je aluzija na distopiju u „Entropiji“, za razliku od romana, $\mathrm{u}$ kom sličan motiv ne postoji. Pinčonova okolina koju stvara $\mathrm{u}$ delima nije distopijska u klasičnom smislu, ali u kratkoj priči strukturalna metafora distopijskog sveta postoji: dobro je gore, loše je dole. Stanovi u njoj predstavljaju „distopiju u malom“, gde su gore oni koji se provode, žive i upražnjavaju sve vrste poroka, dok su dole Kalisto i Obada, koji su izolovani, zaboravljeni, sami. Međutim, kontrasti nalik ovakvim distopijskim su česti i u kratkoj priči i u romanu.

Još jedan postmoderni karakterisični sastojak jeste metafikcija. U Pinčonovoj književnosti se ona ne može naći kao u Bartovim delima, u kojima on doslovno koristi metajezik umesto odabranih prideva, glagola ili imenica, čime izaziva grešku u matrici književnosti: „Kratki spojevi, kojima je prezasićena postmoderna fikcija, retko se pojavljuju u drugim vrstama fikcije“" (Lewis, 1998: 131). Iskusnim čitaocima će, uprkos tome, teško promaći nešto što bi se moglo okarakterisati kao „meta“ u Objavi broja 49: „Postmodernizam često od postupka čitanja pravi temu. Ako je značenje rezultat interakcije između teksta i čitaoca, onda je drama postmoderne književnosti drama interpretacije. Stoga, heroina Pinčonove Objave broja 49 pročešlja ogroman broj dokaza da bi ,projektovala svet ${ }^{\text {‘“‘ }}$ (Steiner, 2007: 445). Ona čita i istražuje dokaze koji će joj pomoći u tome da stvori sliku o tome šta se dešava, istovremeno kada i mi čitamo roman i pokušavamo da shvatimo šta se u njemu zapravo dešava. Mi smo Edipa, a ona piše sopstvenu priču.

Ni u jednom ni u drugom delu ne možemo pronaći kiborge i androide, iako su česti u ovom književnom pravcu: „Dona Haravej je uvela kiborge kao metaforu za postmoderne subjekte. [...] hibridan subjekat, koji time što negira razlike između čoveka i mašine izaziva ustanovljene granice i binarne dihotomije" (Taylor i Winquist, 2001: 77). Kiborzi se mogu uočiti u delima svih medija, bilo književnosti (Sanjaju li androidi električne ovce), ili filma (od Ratova zvezda do Ederlezi Rising), uvek sa pitanjem da li su oni humaniji od samih ljudi, koji su nasuprot tome postali nalik 
robotima. Izveštačenost ljudi je kod Pinčona radije prikazivana njihovim manjkom kontakta, njihovom neuviđavnošću prema drugima i apatijom. Pa ipak, u Objavi broja 49, u jednom specifičnom citatu se oni pojave, a zatim zauvek nestanu, gde se govori o automobilu kao o njihovom delu tela. „A i kako ne bi, nakon što je video ljude koji su siromašniji od njega kako dolaze, crnci, Meksikanci, južnjaci, parada sedam dana u nedelji, i donose najgore moguće stvari u zamenu: motorizovane, metalne produžetke sebe, svojih porodica i onoga što mora da je njihov život..." (Pynchon, 2012: 5) - prodavanje, tj. zamena automobila se poredi sa sakaćenjem, kao kada se androidima zameni jedan deo tela za model „novije generacije“.

Prikladno je započeti komparativnu analizu motivom koji se nalazi na samom početku oba dela - žurkama. I u romanu i u kratkoj priči se spominje divlji skup sa alkoholom i psihoaktivnim supstancama. Žurke su „teren“, gde se mogu na jednom mestu naći mnogi drugi motivi. Na početku Objave broja 49, Edipa Mas se vratila sa žurke gde je previše popila, dok je u „Entropiji“ žurka zašla u četrdeseti sat. Zloupotreba i upotreba alkohola i psihoaktivnih supstanci je česta unutar ovakvog okruženja, ali i van njega: „Na kuhinjskom podu, usred gomile praznih flaša od šampanjca, bili su Šandor Rohas i tri prijatelja. Igrali su poker i ostajali budni pomoću šampanjca i pilula amfetamina“ (Pynchon, 1959: 1). U Objavi broja 49, pominje se i LSD i lekovi koje domaćice uzimaju u okviru kliničkog istraživanja. Rastrzanost između dostupnosti droge i lekova i paranoje oko istih su izražen postmodernistički kontrast, kao i motiv farmaceutske industrije (,Nemoj dozvoliti da te Frojdovci nagovore na suprotno, ili da farmaceuti otrovom izbace to iz tebe!" (Pynchon, 2012: 133) - ovakav tip „big pharma“ teorije zavere doprinosi preovladavajućem osećaju paranoje u postmoderni, o kojoj će kasnije biti reč). Međutim, i droga i alkohol se koriste kao beg od realnosti, radi stvaranja nečeg nalik Bodrijarovom simulakrumu.

Simulakrum je sveprisutan u postmoderni, bilo u obliku virtuelne realnosti, ili onakve realnosti kakvu mi želimo, kakvu sami stvaramo za sebe: „Žan Bodrijar uspostavlja kulturu hiperrealnosti kojom dominiraju simulacije, predmeti i diskursi kojima nedostaje fiksirani označitelj ili osnova“" (Taylor i Winquist, 2001: 369-70). Sam Bodrijar je poredio ovaj fenomen sa Diznilend kulturom gde je mašta jednaka stvarnosti, rekavši da se brišu granice (kao i uvek u postmodernizmu) između toga šta postoji, a šta je simulakrum, jer međusobno utiču jedno na drugo: „Psihologija 
i medicina prestaju u ovom trenutku, jer su preduhitrene neotkrivenom istinom o bolesti. Jer ako se svaki simptom može ,proizvesti““ i ne može se više smatrati prirodnom činjenicom, onda se može smatrati da se svaka bolest može simulisati i jeste simulisana, te medicina gubi na značaju jer jedino ume da leči ,prave“ bolesti u skladu sa njihovim objektivnim uzrocima“" (Baudrillard, 1994: 3). Dakle, svako u savremenom svetu stvara sopstveni univerzum i ima opciju da u njemu i ostane, kao što je i San Narciso produkt Pirsovog bogatstva i samovolje: "Jer Edipa vidi znakove i predskazanja gde god da ide - a njena putovanja je vode duž obale Kalifornije između Los Anđelesa i San Franciska. Kada ulazi u San Narciso, dom saizvršioca, odjednom ima viziju grada koji je raširen ispred nje kao ogromno odštampano strujno kolo " (Seed, 1976: 76-7).

U „Entropiji“ se takav simulakrum vidi na primeru Kalista, koji se hermetički zatvorio u sopstveni stan, gde je napravio sopstvenu realnost i pravila, u kojima živi potpuno odsečen od spoljašnjeg uticaja, ljudi, pa čak i temperature, nalik ljudima koji su u igrici i nose VR naočare. U Objavi broja 49 je primetan na više mesta. ,„,To je ova grupa u kojoj sam,” Majls je objasnio, „Paranoidi. Novi smo. Naš menadžer kaže da treba tako da pevamo. Mnogo gledamo engleske filmove, radi akcenta." " ovde je simulakrum u njihovom ,imidžu“, pretvaranju članova benda da su nešto što nisu radi stvaranja iluzije uspeha i dopadljivosti. Ovo jeste sindrom savremenog sveta u kom cilj opravdava sredstvo, i gde je bolje postojati kao nešto veštačko, a uspešno, nego kao neko verodostojan. Takođe, simulakrum je proizvod efekta droge: ,„,Uzimaš je jer je dobra. Jer čuješ i vidiš neke stvari, čak i osetiš miris i ukus kao nikada ranije. Jer je svet toliko bogat. Nema kraja, dušo.”“" (Pynchon, 2012: 139).

Simulakrum takođe ukazuje na još jednu bitnu, pomenutu stavku artificijalnost. Sve što je važno, vredno divljenja, napravljeno je veštački, kao akcenat članova Paranoida. O atmosferi u Kalistovom stanu se pažljivo vodi računa (,Hermetički zatvoren, stan je bio majušna enklava pravilnosti u gradskom haosu, a ćudljivost vremena, državne politike ili bilo kakvi građanski nemiri nisu uticali na njega“ (Pynchon, 1959: 3) i podržava argument o kome će se govoriti kasnije - o dehumanizaciji i izolovanosti), dok je istorija u Objavi broja 49 izmenjena ,sve radi zabave ronilačkih entuzijasta“ (Pynchon, 2012: 23), da bi se privukla publika i na površini stvari delovale privlačnije. Ovo je uvod u površan svet, bez dubljeg značenja ili složenosti, koje obesmišljava sve, umetnost (ironično - čak i umet- 
nost postmoderne kada se u Objavi broja 49 Vorfingerovo delo umanjuje na značaju jer nije podjednako „dobro“ kao Šekspir, što će biti citirano u nastavku), pa čak i ljudski život.

Usled droge, medija, izolovanosti i, najznačajnije, simulakruma, likovi ne samo što imaju problema sa smislom, nego i sa identitetom. Kao što istinitost gubi na vrednosti, tako i imena gube na smislu, a značenja im se obesmišljavaju širom postmodernog sveta. Ovakva situacija se završila (u sadašnjosti) apsurdnim imenima koje poznate ličnosti daju svojim potomcima, ali se može sažeti u jednoj jedinoj rečenici kojoj izgovara bokser iz Tarantinovih Petparačkih priča. Buč odgovara taksistkinji da u Americi imena ne znače ama baš ništa. Iako ovde imena nose neka značenja, samim likovima ona ne predstavljaju deo identiteta. Edipino ime ukazuje na Edipov kompleks (na koji se recimo ukazuje kroz lik Rouzmana, advokata - „Rouzman je negovao žestoku ambivalentnost, želeći momentalno da postane uspešan sudski advokat, a pošto je to bilo nemoguće, da ga uništi““ (Pynchon, 2012: 10), ili kroz činjenicu da svi muškarci u liku zgodne domaćice vide nešto privlačno). Njeno ime sadrži psihološko ili ironično značenje kao i dosta ostalih imena iz romana: Manny Di Presso, Pierce Inverarity, Mike Fallopian, San Narciso, Dr Hilarius, Mucho Maas, pa čak i akronim KCUF gde Mućo radi, što je psovka unazad. Muzička grupa se zove po jednom od najupečatljivijih motiva u romanu, ali i u postmodernizmu uopšte. U jednom trenutku identitet postaje toliko beznačajan, da Edipa nakon razgovora sa sopstvenim mužem, koji je zaboravio njeno ime i njeno (a samim tim i svoje) prezime, izgovara „O, zovi me Edna“ (Pynchon, 2012: 135). Odnos postmodernih likova prema sopstvenim imenima ukazuje na njihov labilni osećaj samosvesti, kao i lakoću sa kojom se njihov čitav identitet i „mesto“ u svetu poljuljaju. U „Entropiji“ je zanimljivo ime Šandor Rohas, što ukazuje na dvojno poreklo lika (što dokazuje da je dvojnost i borba sa identitetom postala značajan postmodernistički motiv, koji će se kasnije predstavljati u svim medijima, npr. u seriji Altered Carbon sa glavnim likom koji se zove Takeši Kovač). Osim likova, poništava se i bilo kakav pokušaj traženja dubljeg značenja u bilo čemu (Dribletovo: "Napisano je da bi se ljudi zabavili. Kao horor filmovi. Nije to književnost, nema neko značenje. Vorfinger nije Šekspir.” (Pynchon, 2012: 71)).

Borba sa identitetom i dvojnost likova je dobra metafora za ono što se inače dešava u postmodernizmu - preklapanje žanrova i kontrasti između istih: „Mnogi noviji postmodernisti su fascinirani upravo tom slikom 
reklama i motela, putevima Las Vegasa, večernjim emisijama i drugorazrednim holivudskim filmovima, ili takozvanom paraknjiževnošću sa jeftinim mekim izdanjima o gotici i romantici, popularnim biografijama, krimi misterijama i romanima naučne ili epske fantastike“" (Jameson, 1983: 1-2). Sam roman Objava broja 49 predstavlja mešavinu detektivskog romana, drame, apsurda i naučne fantastike. Oba Pinčonova književna dela o kojima je ovde reč, međutim, koriste pastiš unutar samog dela, spajajući nespojivo (,Parodije ne uništavaju prošlost. U stvari, parodija uporedo ovekoveči prošlost i preispituje je. Ovo je, opet, postmoderni paradoks“" (Hutcheon, 1988: 126), ili, po rečima Luisa: „Pastiš je dakle vrsta permutacije, mešanje generičkih i gramatičkih tikova... Ovo objašnjava zašto mnogi savremeni romani pozajmljuju odoru drugih oblika književnosti““ (Lewis, 1998: 125-6)). Spajaju se i mešaju različite kulture unutar jedne osobe, nauka i umetnost, nauka i apstraktna osećanja, umetnički pravci, tradicija i savremeno, klasična i postmoderna književnost. Primeri za ovakve kontraste sa javljaju u romanu u vidu intertekstualnosti: „Svi tekstovi su slobodni da plivaju, sa svojim bilo lingvističkim, književnim, ili generičkim saputnicima u moru intertekstualnosti gde prethodno prihvaćene razlike između njih nisu bitne " (Butler, 2002: 24). Možemo uzeti za primer Edipino poređenje na samom kraju prvog poglavlja sa damom zatočenom u tornju koja želi da sazna više o magiji koja je tu drži, što uspostavlja vezu između nje i Tenisonove Dame od Šalota (,Takva zatočena gospa, pošto ima mnogo vremena za razmišljanje, ubrzo shvati da je njen toranj, njegova visina i arhitektura, kao i njen ego, samo slučajan: da je ono što je zapravo drži tu gde jeste magija, anonimna i zloćudna, koja je posećuje od spolja i bez ikakvog razloga" (Pynchon, 2012: 14)), ili Mecgerovo poređenje: „Kada se pusti deluje, kao što je Mecger primetio kasnije, kao crtani sa Pticom trkačicom u blankversu“" (Pynchon, 2012: 69).

Ovakvo mešanje žanrova nužno dovodi do stvaranja uočljivih kontrasta. Bilo da je kontrast između dostupnosti droge i paranoje oko uzimanja iste, bogatih i siromašnih (motiv koji se pojavljuje i u filmovima i serijama kao što su Blade Runner, ili Altered Carbon), ili hiperbola u Objavi broja 49 gde se Mućo na poslu susretao sa ljudima kojima znači da uštede 10 centi, ovo nas podseća na spomenute distopijske sredine, koje manjkaju u romanu, ali se na njih suptilno ukazuje u „Entropiji“. Kontrast je između gornjeg i donjeg stana, gde je gornji pun života, alkohola i uživanja, a donji u zaboravu, ali primoran da trpi buku i posledice stanovnika odozgo. 
Kontrast i pastiš takođe leže i u Pinčonovom čuvenom mešanju nauke u fikciju. On je u Objavi spominjao perpetuum mobile, a u „Entropiji“ je Njutnov zakon termodinamike jedan od najvažnijih motiva. Postupkom otvaranja prozora, Obada je poništila svu izolaciju, sav pokušaj da se veštački zaustavi protok vremena, energije, vazduha, temperature; izbacila ih je iz simulakruma. Likovi često spominju teoriju komunikacije i poistovećuju je sa egzaktnom naukom u „Entropiji“, pogotovo kada Sol priča kako ga je ostavila žena. Ljudi očekuju da osećanja, misli i druge ljude objasne naučnim procesima i fizikom, čime se samo udaljavaju jedni od drugih. Međutim, nauka nije jedina koja utiče na društvo, već i društvo utiče na nauku i izaziva njenu komercijalizaciju: „Nauka ne može više dozvoliti da predstavlja nezainteresovanu potragu za istinom o prirodi, pošto je njen ekonomski opstanak vezan za nastajanje nove tehnologije: nauka ne može jednostavno želeti da sazna, ona mora delati“" (Grant, 1998: 75-6). Ovakav pristup ljudima kao da su mašine doprinosi njihovoj dehumanizaciji i izolovanosti od drugih.

Prilikom žaljenja na suprugu, Sol spominje: „Dehumanizovan. Pa koliko humaniji mogu biti? Brinem, Ćufto, zaista“" (Pynchon, 1959: 8), čime nam otkriva još čestih motiva - dehumanizacija i obamrlost usled otuđenosti od drugih: „Ljudi više ne gledaju jedni druge, ali za to postoje institute. Oni se više ne dodiruju, ali postoji kontaktoterapija. Oni više ne hodaju, ali idu da džogiraju“ (Baudrillard, 1994: 13).

Likovi, dakle, koriste spomenute psihoaktivne supstance da bi ubili svoju obamrlost, da bi se naterali da osećaju nešto, makar to bio i simulakrum. A ako je ne osete kao posledicu izmenjenog stanja svesti, oni će je svesno stvoriti, kao Kalisto u „Entropiji“. „U vazduhu je postojao neki osećaj amortizacije, izolacije, primetila je odsustvo intenziteta, kao da gleda film, tek primetno van fokusa, što je filmski operater odbio da ispravi“ (Pynchon, 2012: 12) - Edipa opisuje nedostatak suštine, značenja (onog koje je toliko duboko ukorenjeno da im doseže do identiteta, zbog čega joj sopstveni muž greši ime, zbog čega je i njoj sasvim svejedno ko je ona i kako se zove), a nešto kasnije obezvređuje osećaj slobode na auto-putu, govoreći da je lažan i da je to samo igla u veni jednog grada. Zbog toga piju, ili, kao u „Entropiji“, sedaju pod hladan tuš, ne komuniciraju jer ne znaju kako (kao Sol), ili ne žele (kao Edipa - „Zar ne želiš da znaš šta je rekao?“ „Ne“, reče Edipa i upali televizor (Pynchon, 2012: 21), jer bi radije da konzumiraju), pa se oslanjaju na drogu, alkohol, ili tehnologiju (kao kada je muzička grupa Paranoidi pokušavala da utakne kablove od instru- 
menata u pesak) da bi objasnili ili prespojili komunikacijski jaz. Problem je takođe što su oni navikli i da se svi problemi reše ,,instant“", pri prvom pokušaju, bilo da je reč o Solovom braku ili manjku utičnica na plaži: ,,.. način na koji je naš čitav savremeni društveni sistem malo po malo počeo da gubi kapacitet da upamti sopstvenu prošlost i počeo da živi u večitoj, učestaloj sadašnjosti i večnim promenama koje uništavaju tradiciju“ (Jameson, 1983: 11). Iako kiborzi u klasičnom obliku ne postoje u ova dva dela, očigledno je u šta se ovi likovi pretvaraju. Čak je njihovo viđenje smrti trivijalizovano: „Zašto bi uradio tako nešto?" Rouzman se pitao nakon što je pročitao pismo. „Misliš umro?“ (Pynchon, 2012: 11).

Ono što proizilazi iz te obamrlosti je sledeće: bezobzirnost prema moralno ispravnom (na primer kapitalističko uništavanje groblja bez pitanja radi izgradnje auto-puta iz Objave), obezvrednjavanje ideala (,Da li je tako umro, pitala se, među snovima, smrskan od strane jedine ikone u kući? To ju je samo zasmejavalo“ (Pynchon, 2012: 2)) i potpuna ravnodušnost prema drugima: „Neko pokušava da uđe kroz prozor. Provalnik, ja mislim. Pljačkaš“‘. „Šta brineš, mi smo na trećem spratu ${ }^{26 ،}$ (Pynchon, 1959: 5). Ravnodušni, a rešeni da predstave drugima dopadljivi simulakrum, likovi su primorani na izveštačene reakcije: „Kako se osećate po ovom pitanju? “ „Grozno”, reče Edipa. „Predivno,” reče Mućo (Pynchon, 2012: 134).

Usled obamrlosti, konzumiranja kao zamene za emocije i manjka komunikacije, njima je i ljubav problematična. Edipa kao da nema osećanja ni prema kome, ravnodušno „plovi“ kroz život. Oni ne mare za afere, a seks je sveden na površan fizički akt, na ekonomsku transakciju: „Samo telo se može posmatrati kao potrošačka roba, i ovo je postupak koji je dostupan i koji se promoviše i muškarcima i ženama. U ovako konkurentnom svetu nije dovoljno biti običan i svi smo ubeđivani da treba da se probližimo što više idealu mladalačkog telesnog savršenstva da bismo sebi dodali na tržišnoj vrednosti“" (Watson 1998: 56). Zbog svoje potrebe da osećaju bilo šta, oni normalizuju poremećene, dekadentne radnje i nikoga nije briga, jer sve opravdava osećaj otupelosti (od osmogodišnjakinja i petnaestogodišnjakinja sa kojima se primetan broj ljudi zabavlja u Objavi, do direktnog pitanja mornara koliko devojke naplaćuju u „Entropiji“). Ljubav je ovde predstavljena kao nešto znatno gore od bilo kog fizičkog čina: „To su Anonimni inamorati. Inamorato je neko ko je zaljubljen. To je najgora

2 U originalu stoji second-story man, tj. provalnik koji konkretno ulazi kroz prozor na drugom spratu, prim. prev. 
zavisnost od svih“, „Od ovog dana se zaklinjem da se odričem svih vrsta ljubavi: hetero, homo, bi, sa psima, mačkama, automobilima, svih vrsta koje postoje“ (Pynchon, 2012: 107, 111). Međutim, iako je ljubav trivijalizovana i svedena na seks, kao u slučaju Edipe koja je navikla da je gledaju kao da je komad mesa, njoj takođe smeta ukoliko u prostoriji niko nije zainteresovan za nju. Dakle, njima ne fali druga osoba, kontakt, dodir, intima (jer je pitanje da li su postmoderni likovi svesni postojanja drugih pored sopstvene sebičnosti), već pažnja i validacija u vidu seksualnog interesa, samo simulakrum i privlačnost prema površinskom, reklamiranom - što su sve faktori koji su uticali na uključenje pornografije u postmodernu umetnost: „....̌sto je smestilo pornografiju u centar postmoderne književnosti... Svakako je istina da kategorija pornografije deluje sve manje i manje značajna u skorijoj ozbiljnoj fikciji, ali ono što je još bitnije za postmodernizam od ove relativizacije moralnosti jeste to što je pornografija validacija ličnih fantazija. Rad pornografije predstavlja nesputani alternativni svet..." (Steiner, 2007: 446).

Normalizacija seksualnih perverzija nije jedini prikaz apsurda, već postoji i apsurdna veza između događaja, likova i reakcija, koja je već pomenuta u ovom radu. Čitava kratka priča opisuje apsurdnu žurku, gde muzičari sviraju nepostojeće instrumente, devojke spavaju u lavabou, ljudi ulaze kroz prozor i drže pištolje kao igračke. Roman takođe sadrži bezbroj ovakvih scena: „Postojao je nekakav je ne sais quoi u gostima Skoupa: svi su nosili naočare i nemo zurili u vas. Izuzev njih dvoje-troje bliže vratima, koji su bili u sred takmičenja iz čačkanja nosa i proveravali koliko daleko mogu da dobace preko prostorije.“; „Debelo dete, koje je izgledalo izmaltretirano, popelo se na šank i počelo da proziva imena i da baca koverte $u$ gomilu ljudi“ (Pynchon, 2012: 40, 44). Vrhunac apsurda je scena u kupatilu, kada je Edipa obukla toliko slojeva odeće da se prevrnula i oborila dezodorans, koji je krenuo da leti po sobi: „Ovakav napad na realizam je od ključne važnosti za sve prste postmoderne aktivnosti““(Butler, 2002: 27).

Važno je napomenuti i karakterističnu ne-linearnost događaja: „Ako se složimo da život nikada nije linearan, da je život zapravo haotičan i nepovezan jer se nikada ne iskusi pravolinijski ili sa redom, onda takva linearna, hronološka i sekvencijalna naracija više nije moguća“ (Federman, 2001: 70). Bilo da je to odstupanje od hronološkog redosleda, ili, kao kod Pinčona, kroz suptilne naznake, kao kada se Edipi pokvario sat, ili kada je rekla da se ne seća koji događaj se prvo desio. Protok vremena je relativan, ona ne zna koliko se gde zadržava, osećaj stagnacije je sveprisutan. U 
„Entropiji“ je prikazan kroz stanje u kom su Kalisto i Obada, zamrznuti u vremenu i simulakrumu.

Pop kultura, medijska manipulacija i konzumerizam su takođe česti motivi: „U postmodernom svetu, najosnovniji postulat je: Kupujem, dakle postojim“ (Watson, 1998: 63). I u „Entropiji“ i u Objavi broja 49 se govori o džez muzici, i kroz reklame implicira na poznata kulturološka obeležja (,Sada je gledala poznati portret Ujaka koji se pojavljuje ispred svih američkih pošta, njegove oči su nezdravo svetlucale, njegovi upali, žuti obrazi nasilnički zajapureni, a prst mu je bio uperen između njenih očiju. Želim tebe“ (Pynchon, 2012: 9)). Popularna kultura se širi celim svetom zahvaljujući globalizmu, postavši globalna kultura, što i mi i Pinčonovi likovi rado usvajamo: „Dajemo novac i zabavlja nas da konzumiramo polovna iskustva koja su nekada bila osnova društvenog života. U velikoj meri smo postali turisti u sopstvenim kulturama“"(Watson, 1998: 55).

Mediji i televizija su sami po sebi simulakrumi: „Mi smo prosto zatvoreni u svetu znakova kojim dominiraju mediji, koji je zloćudno stvorio kapitalizam radi sinteze naših želja, koje zapravo samo upućuju jedna na drugu unutar zarobljavajućeg kruga ideja. One su prost simulakrum, koji funkcioniše kao zamena postojećim stvarima i pravim odnosima" (Butler, 2002: 114). Njihova svrha jeste beg od realnosti, kao droga, kao alkohol, a svemu tome naši likovi pribegavaju ,da bi nam pomogli da zaboravimo, da nam služe kao agensi i mehanizmi za našu istorijsku amneziju“ (Jameson, 1983: 12). Zbog toga, likovi su konzumenti i žrtve mode i reklama: „Put je prošao bez nekih zanimljivih dešavanja, izuzev dva ili tri sudara koje su Paranoidi zamalo izazvali zahvaljujući Seržu, vozaču, koji nije mogao da vidi kroz šiške" (Pynchon, 2012: 48). Oni (a samim tim i njihovi međusobni odnosi) nisu jedine žrtve medija, već je i nauka, koja je primorana da stvara radi konzumiranja.

Kao element koji objedinjuje konzumerizam, obamrlost, apatiju i medijsku manipulaciju, postoji osećaj paranoje koja može doći do granice sa histerijom. Ihab Hassan tvrdi da je paranoidnost modernistička, dok je šizofrenija postmodernistička (Hassan, 1993: 152). Međutim, jednako šizofreniji, paranoja je veoma stvaran i učestali motiv ovog pravca: „Postmoderna dela su umnogome odraz paranoidne anksioznosti u koje spada: nepoverenje prema fiksnosti, prema ograničenosti na jedno mesto ili identitet, ubeđenje da društvo kuje zaveru protiv individua i umnožavanje ličnih teorija zavere u inat tuđim" (Lewis, 1998: 130) - što povezuje mnoge elemente o kojima je do sada bilo reči. 
Kalisto je paranoičan da će kontakt sa svetom dovesti do njegove potpune propasti, a Edipa je prvenstveno paranoična oko farmaceutske industrije: ,„..Kako vam se čine pilule, zar ne funkcionišu?“ [Oedipa] „Ne uzimam ih”, rekla je. „Osećaš se ugroženo?“ „Ne znam šta je u njima“... Prekinula je vezu. I onda nije mogla da zaspi. Ali prokleta bila ako uzme kapsule koje joj je dao. Bukvalno prokleta“"(Pynchon, 2012: 8-9). Njeno nepoverenje dovodi u pitanje kontrolu nad masom preko lekova, ali i preko televizije: „Ili je on [Mecger] sve to izmislio, Edipa je naprasno pomislila, ili je podmitio inžernjera koji radi za lokalnu stanicu da pusti ovo. Sve je to deo zavere, složene, zavodljive zavere" (Pynchon, 2012: 23). Kasnije, ona postaje paranoična i oko Tristera, oko Pirsa i njegove smrti, kao i da je sve to nameštaljka. Paranoja likova dovodi do motiva teorija zavere, koje su centralni motiv u Objavi broja 49, do te mere da se dovodi u pitanje da li su istorijski događaji zapravo „,namešteni“: „U sadašnjosti oni prkose državnom monopolu i rukovode tajnom mrežom koja povezuje delove kalifornijskih velikih preduzeća sa podzemljem. Složenost Pinčonovih argumenata i preciznost njegovih referenci na istoriju čine sve povezanosti ubedljivim, iako je celokupna slika apsurdna” (Seed, 1976: 78). U „Entropiji“ su ti motivi, između ostalog, izraženi i kroz Mirijam: „Mirijam je opet krenula da čita naučnu fantastiku. To i časopis Sajentifik Amerikan. Deluje da je, kako bi se reklo, uznemiruje ideja da se računari ponašaju kao ljudi. Pogrešio sam jer sam joj rekao da se to sa lakoćom može preokrenuti i razgovarati o ljudskom ponašanju kao da je program koji je pohranjen u IBM mašinu 3“" (Pynchon, 1959: 8).

Na kraju svih motiva, kao završni, imamo antiklimaks. Objava broja 49 se završava kao da nikada nije ni počinjala - bez zaključka, sa neizvesnošću, Edipa i dalje traga za objašnjenjem i smislom (što je samo po sebi ironično). U „Entropiji” postoji kontrast kraja na dva sprata. Kod Kalista i Obad, simulakrum se razbija i uspostavlja se kontakt sa spoljašnjim svetom. Vreme se zamrzava u trenutku radi toga da bi ponovo krenulo da teče za dvoje zarobljenika u stanu - naglo, naprasno, nasilno, neizvesno. Žurka kod Ćufte Muligana se završava tako što se razbija tenzija - situacija se smiruje, bez peripetija, nalik izduvanom balonu. Osećamo da se približava radnja kulminaciji (izbija tuča, ljudi se gađaju balonima punim vode, devojka kreće da se davi u kadi), a onda, umesto očekivane eksplozije, čitalac dobija deaktivaciju bombe, osećaj kakav postmodernistički likovi verovatno imaju prilikom vođenja ljubavi, ili generalno u životu,

IBM - International Business Machines coorporation, prim. prev. 
taj faličan osećaj nedostajanja nečega, svrhe, kraja, zaključka: „Surfikcija će naizgled biti lišena značenja, biće svrsishodno nelogična, iracionalna, nerealna, non sequitur, digresivna i nekoherentna. I, naravno, pošto priča o surfikciji neće imati početak, sredinu ni kraj, ona neće biti podložna neprestanom i sjedinjavajućem obliku čitanja. Ona će odbijati razrešenja i zaključke" (Federman, 2001:74).

\section{ZAKLJUČAK}

Postoji mogućnost da ćemo i mi završiti kao naši voljeni likovi i da ćemo u izolaciji, nalik Kalistovoj, potpuno poludeti i krenuti da obezvređujemo ideale, zakone logike i morala, okrenuti se zloupotrebi supstanci ili izgubiti želju za napretkom. Moguće je i da ćemo postmodernistički zazirati od postojanja, pa čak i od samih sredstava kojima ispunjavamo osećaj obamrlosti: „Na sopstveni teatralni, prenaglašeni način, pop art je predstavio u potpunosti novi pristup egzistencijalnom užasu i strahu od tehnologije, pošto su isti već bili iskazivani u modernističkim delima“" (Steiner, 2007: 437).

Možda će i nama divlje, četrdesetosatne žurke biti glavni lek nakon ovog našeg rata 2020. godine. Ne znamo ni da li će nas sopstvena paranoja dovesti do svojevrsne apokalipse i opravdavanja neprihvatljivog ponašanja samo radi toga da bismo nešto osetili, ili ćemo, kao Kalisto, svako za sebe negovati ptičicu, truditi se da ona bude simbol toga da se borimo protiv promene na gore. U svakom slučaju, društvo napreduje, a svako se zasebno treba boriti protiv antiklimaksa i otupelosti, ali i potruditi da uživa u entropiji svakodnevnog života i njegovom apsurdu.

\section{LITERATURA}

Baudrillard, J. (1994). Simulacra and Simulation. Ann Arbor: University of Michigan Press

Butler, C. (2002). Postmodernism: A Very Short Introduction. New York: Oxford University Press.

Dickstein, M. (2007). Fiction and Society, 1940-1970. In S. Bercovitch (ed), The Cambridge History of American Literature (pp. 101-224). New York: Cambridge University Press.

Federman, R. (2001). Surfiction: Writing with No Restraints. In D. Maus (ed), Postmodernism: the Greenhaven Press Companion to Literary Movements and Genres(pp. 66-75). New York: Greenhaven Press Inc. 
Sofija D. Stefanović

Grant, I. H. (1998). Postmodernism and Science and Technology. In S. Sim (ed), The Routledge Companion to Postmodernism (pp. 53-64). London: Routledge.

Harper, P. B. (1994). Framing the Margins: The Social Logic of Postmodern Culture. New York: Oxford University Press.

Hassan, I. (1993). Toward a Concept of Postmodernism. In T. Docherty (ed), Postmodernism: A Reader (pp. 146-156). New York: Columbia University Press.

Hutcheon, L. (1988). A Poetics of Postmodernism: History, Theory, Fiction. New York: Routledge.

Jameson, F. (1983). Postmodernism and Consumer Society. University of California, Santa Cruz. https://art.ucsc.edu/sites/default/files/Jameson_Postmodernism_and_Consumer_Society.pdf

Lewis, B. (1998). Postmodernism and Literature. In S. Sim (ed), The Routledge Companion to Postmodernism (pp. 121-133). London: Routledge.

Macura, S. (2014). Prostorno-vremenska tačka gledišta u pripovijetkama Tomasa Pinčona. Komunikacija i kultura online, 5, 169-186. [on-line]. Dostupno preko: http://www.komunikacijaikultura.org/index.php/kk/article/ view/104/72 [19.05.2020]

Seed, D. (1976). The Fictional Labyrinths of Thomas Pynchon. Critical Quarterly, 18(4), 73-81. Dostupno preko: https://sci-hub. do/10.1111/j.1467-8705.1976.tb02370.x [5.12.2020]

Steiner, W. (2007). Postmodern Fictions, 1970-1990. In S. Bercovitch (ed), The Cambridge History of American Literature (pp. 425-528). New York: Cambridge University Press.

Taylor, V. E., Winquist, C. E. (2001). Encyclopedia of Postmodernism. London: Routledge.

Watson, N. (1998). Postmodernism and Lifestyles. In S. Sim (ed), The Routledge Companion to Postmodernism (pp. 53-64). London: Routledge.

\section{IZVORI}

Pynchon, T. (1959). Entropy. Institute of Physics Gleb Wataghin, São Paulo. https://www.ifi.unicamp.br/ cabrera/teaching/Entropy\%20de $\% 20$ Pynchon.pdf

Pynchon, T. (2012). The Crying of Lot 49. New York: The Penguin Press. 


\title{
Sofija Stefanović
}

\section{COMPARATIVE ANALYSIS OF POSTMODERN ELEMENTS IN ENTROPY AND THE CRYING OF LOT 49}

\begin{abstract}
Summary
This paper explores popular elements and motifs which can be found in literature and postmodern art, with specific focus on the works of Thomas Pynchon. By means of comparative analysis, his short story Entropy and the novel The Crying of Lot 49 shall be inspected. The connection between the two oeuvres will be pointed out, alongside the development of elements that can be found in Entropy, which entailed their later application within the novel itself. Some of the elements analised are: simulacrum, identity, dehumanisation, genre overlap, numbness and causing numbness by (ab)using various psychoactive substances, consumerism, media manipulation, etc. Likewise, postmodern characteristics which are not shared by both the novel and the short story, but appear in one or the other, will be briefly mentioned. Consequently, this paper is a comparative analysis of Entropy and The Crying of Lot 49, yet furthermore an individual analysis of each respective oeuvre through the prism of postmodernism and her motifs.
\end{abstract}

Key words: Entropy, The Crying of Lot 49, Thomas Pynchon, postmodernism, comparative analysis, postmodern motifs. 